\title{
High-performance alkali-activated composites containing an iron-ore mine tailing as aggregate
}

\author{
Raquel P. Batista ${ }^{1}$, Juliana O. Costa ${ }^{1 *}$, Paulo H. R. Borges ${ }^{1}$, Flávio A. dos Santos ${ }^{1}$ and Fernando S. Lameiras ${ }^{2}$ \\ ${ }^{1}$ Department of Civil Eng., CEFET-MG, Av. Amazonas, 7675, Belo Horizonte, 30510-000, Brazil \\ ${ }^{2}$ Centro de Desenvolvimento da Tecnologia Nuclear, CDTN, Av. Presidente Antônio Carlos, 6627, Belo Horizonte, $31270-$ \\ 901, Brazil
}

\begin{abstract}
High-performance cementitious composites have been developed to overcome the brittleness of mortars and concretes, thus improving the deformation and toughness of these materials under flexion and tension. Poli Vinyl Alcohol (PVA) fibres are employed in the production of such "Engineered Cementitious Composites" - ECC; the PVA fibres have a loadcarrying capacity after the first crack (matrix failure), which changes the mechanical behaviour of the composites from brittle to ductile and significantly increases the ultimate strength. This deflection or strain-hardening behaviour is accompanied by a multiple cracking of the composites, which results from the design of a proper formulation, with correct amount of PVA fibres (usually $2 \%$ vol. fraction) and employment of a very fine sand (passing $0.6 \mathrm{~mm}$ ). Recent developments in the area of ECC comprise the replacement of Portland cement (PC) matrices with alkali-activated materials (AAM). The idea is to produce composites with similar performance but with improved chemical durability and lower environmental impact. A more sustainable solution would consider the replacement of the fine sand with mine tailings in the production of ECC-AAM. Some tailings from the iron-ore mining activities in Brazil are significantly finer than those aggregates used for PC mortars and concretes; therefore, they cannot be employed in traditional PC-based materials. Nevertheless, those fine materials could replace the fine natural aggregate used in the production of ECC. This paper investigates the replacement of a natural quartz sand with an iron-rich mine tailing in PVA-reinforced AAM. Four composites were studied from a combination of two different matrices and 2 different aggregates. The matrices were obtained from the alkaline activation of metakaolin (MK) with sodium silicate $\left(\mathrm{Na}_{2} \mathrm{SiO}_{3}\right)$ and sodium hydroxide $(\mathrm{NaOH})$; silica fume (SF) was used to adjust their composition: $\mathrm{SiO}_{2} / \mathrm{Al}_{2} \mathrm{O}_{3}$ molar ratio equal to 3.0 or 3.8. The aggregates used were either natural quartz (passing $0.6 \mathrm{~mm}$ ) or tailings produced during the mining activities of iron ore in the state of Minas Gerais, Brazil. The mine tailing studied is much finer than the natural sand (passing $0.3 \mathrm{~mm}$ ) but it was used as received in the production of ECC-AAM. The aggregate to binder ratio was kept constant (equal to 1.0 in mass) irrespective of the type of aggregate. All mortars were reinforced with $2 \%$ vol. of PVA fibres; extra water was added to the mixes to maintain the same consistency for the composites. The mechanical properties investigated are compressive strength, flexural strength and toughness. The apparent dry density of the mortars was also assessed. The preliminary results presented in this paper indicate that iron-rich tailings may be effectively used in the production of ECC-AAM; however, durability tests are still necessary.
\end{abstract}

\section{Introduction}

Alkali-activated materials (AAM) can be defined as inorganic polymers obtained by the reaction between an aluminosilicate source (such as metakaolin, fly ash, blast furnace slag, silica fume, among others) and an alkaline activator solution [1-4]. Several studies point out that these materials may present several advantages to Portland cement (PC) composites, mainly in terms of lower carbon emissions [5, 6], early strength development [7], superior thermal [8,9] and chemical durability [10-12]. Despite those advantages, AAM are inherently brittle materials and, similarly to PC matrices, may have their mechanical properties improved by fibre reinforcement. Increasing interest in the development of fibre-reinforced AAM has been recently reported, with the employment of a great variety of fibres. Poly vinyl alcohol (PVA) fibres stand up as a good option of reinforcement as they are highly stable in alkaline environment. Those fibres have already been used in the development Engineered Cementitious Composites (ECC) and alkali-activated composites, either presenting

\footnotetext{
Corresponding author: julianacosta@hotmail.com
} 
deflection or strain-hardening behaviour after first cracking under tensile stresses, followed by high ductility [13-15].

Increasing interest in AAM is directly related to their low environmental impact when compared to PC-based materials. Therefore, some studies aim to apply a wide variety of waste and tailings as aggregates or fine materials (precursors or fillers) in AAM [16-21]. Researches on the employment of mining by-products as substitutes for natural aggregates in AAM have increased in the recent decades [19-21]. This arises due to the significant increase in their generation and as an effort to prevent and mitigate the risks of waste accumulation and disposal in dams, as usual in Brazil [22-21]. This paper aims to investigate the effects of replacement of a natural quartz sand with an iron-rich mine tailing on the mechanical performance of two different PVA-reinforced alkali-activated mortars. The AAM were made from the alkaline activation of MK. Silica fume (SF) was used in order to alter the composition of the matrices (namely $\mathrm{SiO}_{2} / \mathrm{Al}_{2} \mathrm{O}_{3}$ molar ratio) without significant changes in the composition of the activation solution $\left(\mathrm{Na}_{2} \mathrm{SiO}_{3}+\mathrm{NaOH}\right)$.

\section{Materials and methods}

\subsection{Raw materials and formulation of the alkali activated composites}

\subsubsection{Materials}

The AAM produced were obtained by the activation of metakaolin (MK) and silica fume (SF), supplied by Metacaulim do Brasil and Tecnosil ltda., respectively. The latter was used to partially replace MK and alter the composition of the matrices, as it is composed mainly of $\mathrm{SiO}_{2}$. The aggregates employed were either natural quartz sand (passing $0.6 \mathrm{~mm}$ ) (supplied by Moinhos Gerais, Brazil) or a mine tailing (passing $0.3 \mathrm{~mm}$ ) from iron-ore mining in the state of Minas Gerais, Brazil. The chemical composition and $\mathrm{X}$-ray diffraction pattern (XRD) of those precursors and aggregates are presented in Table 1 and Figure 1, respectively.

Table 1. Chemical composition of the solid precursors and mine tailing

\begin{tabular}{|l|c|c|c|c|}
\hline $\begin{array}{c}\text { Main oxides and } \\
\text { physical properties }\end{array}$ & $\begin{array}{c}\text { MK } \\
(\%)\end{array}$ & $\begin{array}{c}\text { SF } \\
(\%)\end{array}$ & $\begin{array}{c}\text { Natural } \\
\text { Aggregate } \\
(\%)\end{array}$ & $\begin{array}{c}\text { Tailing } \\
(\%)\end{array}$ \\
\hline $\mathrm{SiO}_{2}$ & 43.55 & 93.40 & 98.75 & 82.78 \\
\hline $\mathrm{Al}_{2} \mathrm{O}_{3}$ & 37.00 & 0.75 & 0.62 & 2.35 \\
\hline $\mathrm{K}_{2} \mathrm{O}$ & - & 1.25 & 0.1 & 0.1 \\
\hline $\mathrm{CaO}$ & 0.05 & 0.23 & - & - \\
\hline $\mathrm{MgO}$ & 0.05 & - & - & - \\
\hline $\mathrm{Fe}_{2} \mathrm{O}_{3}$ & 2.00 & - & 0.25 & 13.86 \\
\hline $\begin{array}{l}\mathrm{Specific} \text { gravity } \\
\left(\mathrm{g} / \mathrm{m}^{3}\right)\end{array}$ & 2.59 & 2.25 & 2.70 & 2.95 \\
\hline $\begin{array}{l}\mathrm{Mean} \text { particle size } \\
(\mu \mathrm{m})\end{array}$ & 2.12 & 0.37 & - & - \\
\hline Fineness modulus & - & - & 1.03 & 0.14 \\
\hline
\end{tabular}

MK is mostly amorphous and composed mainly of $\mathrm{SiO}_{2}$ and $\mathrm{Al}_{2} \mathrm{O}_{3}$; some XRD peaks for quartz, illite and muscovite indicates impurities in the kaolin source, whereas the peaks for kaolinite show some incomplete dehydroxylation of kaolin during the calcination process. $\mathrm{SF}$ is predominantly composed of amorphous silica; the absence of $\mathrm{Al}_{2} \mathrm{O}_{3}$ will therefore increase the $\mathrm{SiO}_{2} / \mathrm{Al}_{2} \mathrm{O}_{3}$ molar ratio of the matrices when SF replaces MK.
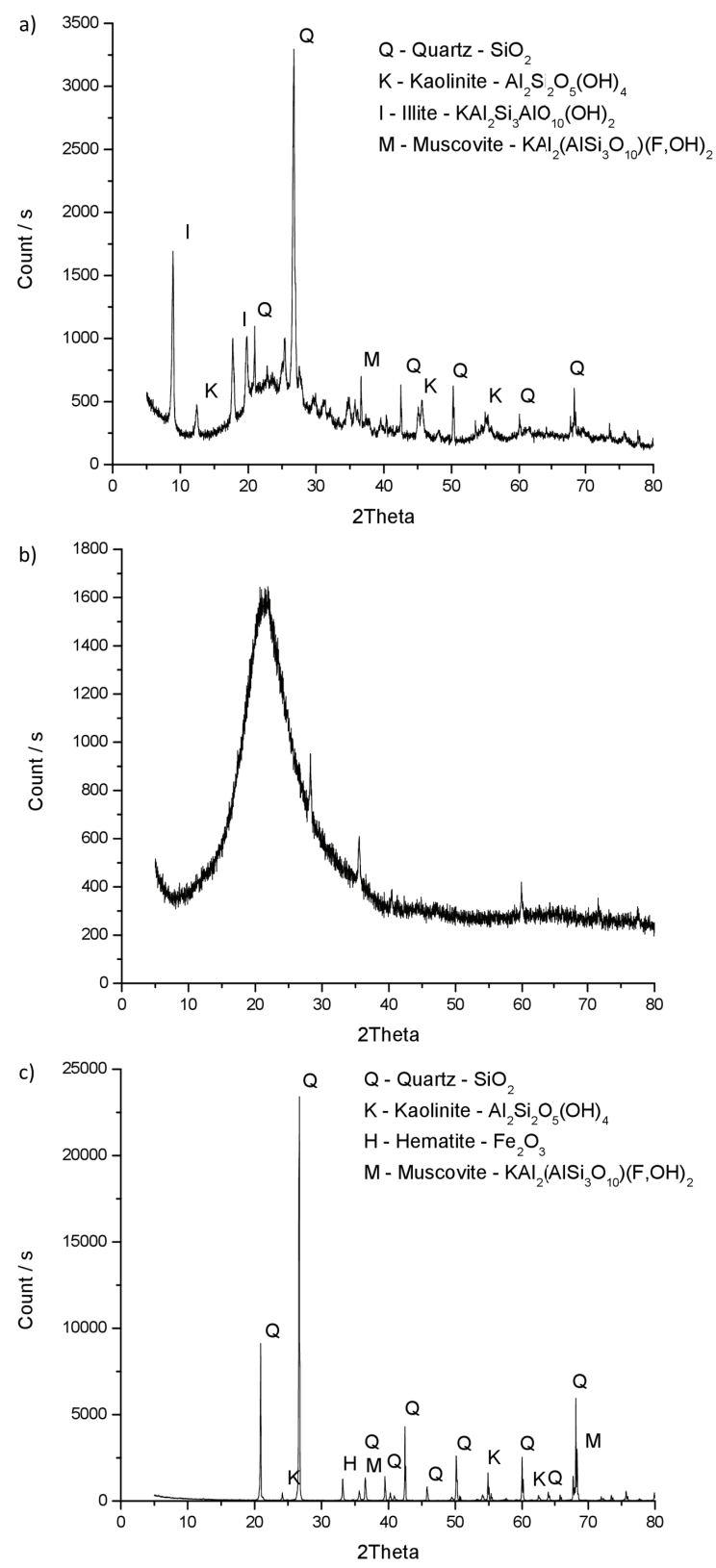

Figure 1. XRD pattern for (a) MK, (b) SF and (c) mine tailing.

The natural aggregate $(98.75 \%$ quartz, XRD not shown) has specific gravity of $2.70 \mathrm{~g} / \mathrm{cm}^{3}$ and fineness modulus equals to 1.03 ; it is a finer aggregate (PSD < $0.6 \mathrm{~mm}$ ) as those commonly used in the production of engineered cementitious composites (ECC). The iron-ore tailing employed as aggregate results from the mining activities in the state of Minas Gerais, Brazil; it is composed of mainly quartz and hematite, with some XRDs peaks for kaolinite probably resulted from contamination (Fig. 1c). It is slightly denser than the natural sand (specific gravity of 2.95) due to the presence of hematite; it is also finer than the natural sand (fineness modulus of tailing $=0.14$ ) but the objective of 
this paper was to use it as received without blending with another aggregate. The Particle size distribution of the natural sand and mine tailing aggregate are shown in Figure 2.

The activating solution was composed of a mix of sodium hydroxide $(50 \%$ vol.) and sodium silicate solutions $\left(\mathrm{Na}_{2} \mathrm{O}=15.00 \%, \mathrm{SiO}_{2}=31.79 \%\right.$ and $\mathrm{H}_{2} \mathrm{O}=$ $53.21 \%$, in \% wt.).

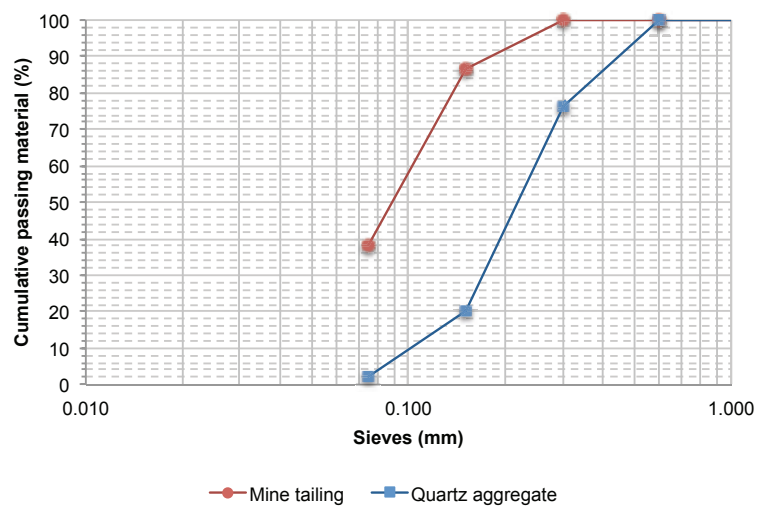

Figure 2. Particle size distribution of the natural (quartz) sand and iron-ore mine tailing.

The short PVA fibres supplied by Kuraray Japan (REC15) have the following properties: diameter: 40 $\mu \mathrm{m}$; length: $8 \mathrm{~mm}$; specific gravity: $1.3 \mathrm{~g} / \mathrm{cm}^{3}$; tensile strength: $1600 \mathrm{MPa}$; Young modulus: $41 \mathrm{GPa}$; elongation: $6 \%$.

\subsubsection{Methods}

The mix design parameters used for the preparation of the AAM are shown in Table 2. Four composites were studied from a combination of two different matrices and 2 different aggregates. Two $\left[\mathrm{SiO}_{2}\right] /\left[\mathrm{Al}_{2} \mathrm{O}_{3}\right]$ molar ratios were adopted: 3.0 and 3.8. The alkaline solutions consisted of a mixture of sodium silicate $\left(\mathrm{Na}_{2} \mathrm{SiO}_{3}\right)$ and sodium hydroxide $(\mathrm{NaOH})$. Although $\mathrm{Na}_{2} \mathrm{SiO}_{3}$ to $\mathrm{NaOH}$ ratio (wt.) varied in each mix, the $\left[\mathrm{H}_{2} \mathrm{O}\right] /\left[\mathrm{Na}_{2} \mathrm{O}\right]$ molar ratio was kept constant in 12,80 for the mortars with natural aggregate and 13,44 for the mortars with the mine tailing aggregate. Solution to binder ratio was kept constant and equal to 1.0. All mortars were prepared with an aggregate to binder ratio of 1.0. The PVA fibres were employed at $2 \%$ vol. fraction in all composites. The alkali-activated mortars were named as follows: NAT for the reference mortars (with natural quartz sand) or MT for mortars with mine tailing as aggregates, both types followed by the $\left[\mathrm{SiO}_{2}\right] /\left[\mathrm{Al}_{2} \mathrm{O}_{3}\right]$ molar ratio and the MKSF wt. content (Table 2).

$\mathrm{SF}$ and $\mathrm{NaOH}$ were mixed 24 hours prior to use, in order to allow complete dissolution of the silica fume particles. The alkaline solutions $\left(\mathrm{Na}_{2} \mathrm{SiO}_{3}\right.$ and $\mathrm{NaOH}$ or $\mathrm{NaOH}+\mathrm{SF}$ ) were mixed together on the day of casting to prepare the liquid component of the mixture. The alkaline activator was firstly added to the MK. The aggregate was then added while mixing for about 5 minutes. After that, the PVA fibres were gradually added while mixing until the mortar presented a homogeneous appearance.

The mortars were cast in $160 \times 40 \times 40 \mathrm{~mm}$ prismatic moulds for the determination of flexural strength and toughness and $100 \times 50 \mathrm{~mm}$ cylindrical moulds for the determination of compressive strength, modulus of elasticity and apparent density. The specimens were exposed to ambient curing conditions until they reached the testing age (14 days).

Table 2. Formulation parameters

\begin{tabular}{|c|c|c|c|c|c|}
\hline Formulation & $\begin{array}{c}\mathrm{SiO}_{2} / \\
\mathrm{Al}_{2} \mathrm{O}_{3}\end{array}$ & $\mathrm{MK}: \mathrm{SF}$ & $\begin{array}{c}{\left[\mathrm{SiO}_{2}\right] /} \\
{\left[\mathrm{Na}_{2} \mathrm{O}\right] \text { in }} \\
\text { activator }\end{array}$ & $\begin{array}{c}\mathrm{Na}_{2} \mathrm{SiO}_{3} / \\
\mathrm{NaOH} \text { wt. } \\
\text { Ratio }\end{array}$ & $\begin{array}{c}\text { Type of } \\
\text { aggregate }\end{array}$ \\
\hline $\begin{array}{c}\text { NAT 3.0 } \\
\text { 100MK- } \\
\text { 00SF }\end{array}$ & 3.0 & $100: 00$ & 1.29 & 1.92 & Natural \\
\hline $\begin{array}{c}\text { MT 3.0 } \\
\text { 100MK- } \\
\text { 00SF }\end{array}$ & 3.0 & $100: 00$ & 1.29 & 1.76 & $\begin{array}{c}\text { Mine } \\
\text { tailing }\end{array}$ \\
\hline $\begin{array}{c}\text { NAT 3.8 } \\
82 \mathrm{MK}- \\
\text { 18SF }\end{array}$ & 3.8 & $82: 18$ & 0.89 & 0.94 & Natural \\
\hline $\begin{array}{c}\text { MT 3.8 } \\
\text { 82MK- } \\
\text { 18SF }\end{array}$ & 3.8 & $82: 18$ & 0.89 & 0.88 & $\begin{array}{c}\text { Mine } \\
\text { tailing }\end{array}$ \\
\hline
\end{tabular}

\subsection{Characterisation}

\subsubsection{Compressive Strength and Modulus of Elasticity}

Compressive strength tests were performed in conformity with the Brazilian standard ABNT NBR 7215 [24]; four specimens for each formulation were tested at the age of 14 days and the results were expressed in terms of the average and standard deviation.

The static modulus of elasticity of the mortars was determined as recommended by ABNT NBR 8522 [25]

\subsubsection{Flexural Strength and Toughness}

The modulus of rupture (MOR) of the mortars was determined in a 3-point flexural test, as described by ASTM C 293 [26]. Four prismatic $(160 \times 40 \times 40) \mathrm{mm}$ specimens were tested for each formulation. An electronic deflectometer with resolution of $0.001 \mathrm{~mm}$ and a maximum measurable deflection of $12.5 \mathrm{~mm}$ was used to measure the displacement of the specimens during the test. The average toughness of the AAM was calculated from the area under the load $x$ mid-span deflection curves.

\subsubsection{Apparent dry density}

Apparent dry density was measured by dividing the mass of oven-dried samples by their volume (cylindrical samples).

\section{Results}

Table 3 shows the compressive strength and modulus of elasticity of the AAM. It is possible to see that the compressive strength results were quite variable, 
presenting large standard deviations. The mean values, however, show that the replacement of the natural sand with the mine tailing aggregate slightly reduced the compressive strength for both matrices. The reduction may be partially explained by the higher water demanded by the composites containing mine tailing as aggregate. The mortars with lower $\mathrm{SiO}_{2} / \mathrm{Al}_{2} \mathrm{O}_{3}$ molar ratios presented higher mean compressive strength, although the standard deviation indicates no statistically significant differences between the figures.

The modulus of elasticity of the formulations containing $100 \% \mathrm{MK}$ did not change with the aggregate type variation. However, the formulation with $82 \% \mathrm{MK}$ and $18 \%$ SF presented a reduction in the modulus of elasticity when the mine tailing aggregate was used. Apparently, this matrix is more sensitive to the type of aggregate or to the variation of the amount of water used in its production. This behaviour needs to be further studied to permit better understanding.

Overall, the results suggest that the replacement of the natural quartz sand with the mine tailing aggregate is detrimental neither to the compressive strength nor to the modulus of elasticity of the mortars.

Table 3. Compressive strength and modulus of elasticity of the composites studied

\begin{tabular}{|c|c|c|}
\hline Composite & $\begin{array}{c}\text { Compressive Strength } \\
\text { (Standard deviation) [MPa] }\end{array}$ & $\begin{array}{c}\text { Modulus of Elasticity } \\
\text { (Standard deviation) [GPa] }\end{array}$ \\
\hline NAT 3.0 & 52.31 & 11.58 \\
100MK-00SF & $(6.01)$ & $(0.59)$ \\
\hline MT 3.0 & 44.45 & 11.58 \\
100MK-00SF & $(3.05)$ & $(0.55)$ \\
\hline NAT 3.8 & 49.50 & 11.88 \\
82MK-18SF & $(2.19)$ & $(0.15)$ \\
\hline MT 3.8 & 45.72 & 10.43 \\
82MK-18SF & $(2.96)$ & $(0.43)$ \\
\hline
\end{tabular}

The results of apparent dry density measured for the four different mortars are shown in Table 4 . The values of apparent dry density were higher when the mine tailing aggregate was employed, regardless of the matrix. Besides, the composites produced with $100 \%$ of MK presented higher apparent dry density than the ones produced with $82 \%$ of $\mathrm{MK}$ and 18 of silica fume. The apparent dry density of the mortars is partially a function of the specific gravity of the raw materials used; therefore, those results can be easily explained. As mentioned in Table 1, SF has specific gravity of 2.25 $\mathrm{g} / \mathrm{cm}^{3}$, while MK has specific gravity of $2.56 \mathrm{~g} / \mathrm{cm}^{3}$; the natural quartz sand has specific gravity of $2.70 \mathrm{~g} / \mathrm{cm}^{3}$ and the mine tailing of $2.95 \mathrm{~g} / \mathrm{cm}^{3}$. Thus, it makes sense that the apparent dry density of the mortars produced (i) decreases with higher SF content; (ii) increases with the replacement of the natural aggregate by the mine tailing. The changes in apparent dry density are always lower than $8 \%$, which confirms that the employment of this mine tailing at this replacement level does not change the density of the products significantly.

Table 4. Apparent dry density of the studied composites

\begin{tabular}{|c|c|}
\hline Composite & Apparent dry density $\left(\mathbf{g} / \mathbf{c m}^{\mathbf{3}}\right)$ \\
\hline NAT 3.0 & 1,678 \\
\hline 100MK-00SF & 1,750 \\
\hline MT 3.0 & \\
100MK-00SF & \\
\hline
\end{tabular}

\begin{tabular}{|c|c|}
\hline NAT 3.8 & 1,612 \\
82MK-18SF & 1,665 \\
\hline MT 3.8 & 82MK-18SF
\end{tabular}

Figures 3 and 4 show the load (N) x mid-span (mm) deflection curves for the AAM studied after third-point loading tests. All the composites presented multicracking behaviour after bending tests typical from AAM containing 2\% PVA fibres.

Irrespective of the type of aggregate, a higher $\mathrm{SiO}_{2} / \mathrm{Al}_{2} \mathrm{O}_{3}$ molar ratio decreased the first peak and peak strength (Figure 5) with consequent increase in the deflection and toughness of the PVA-AAM. 

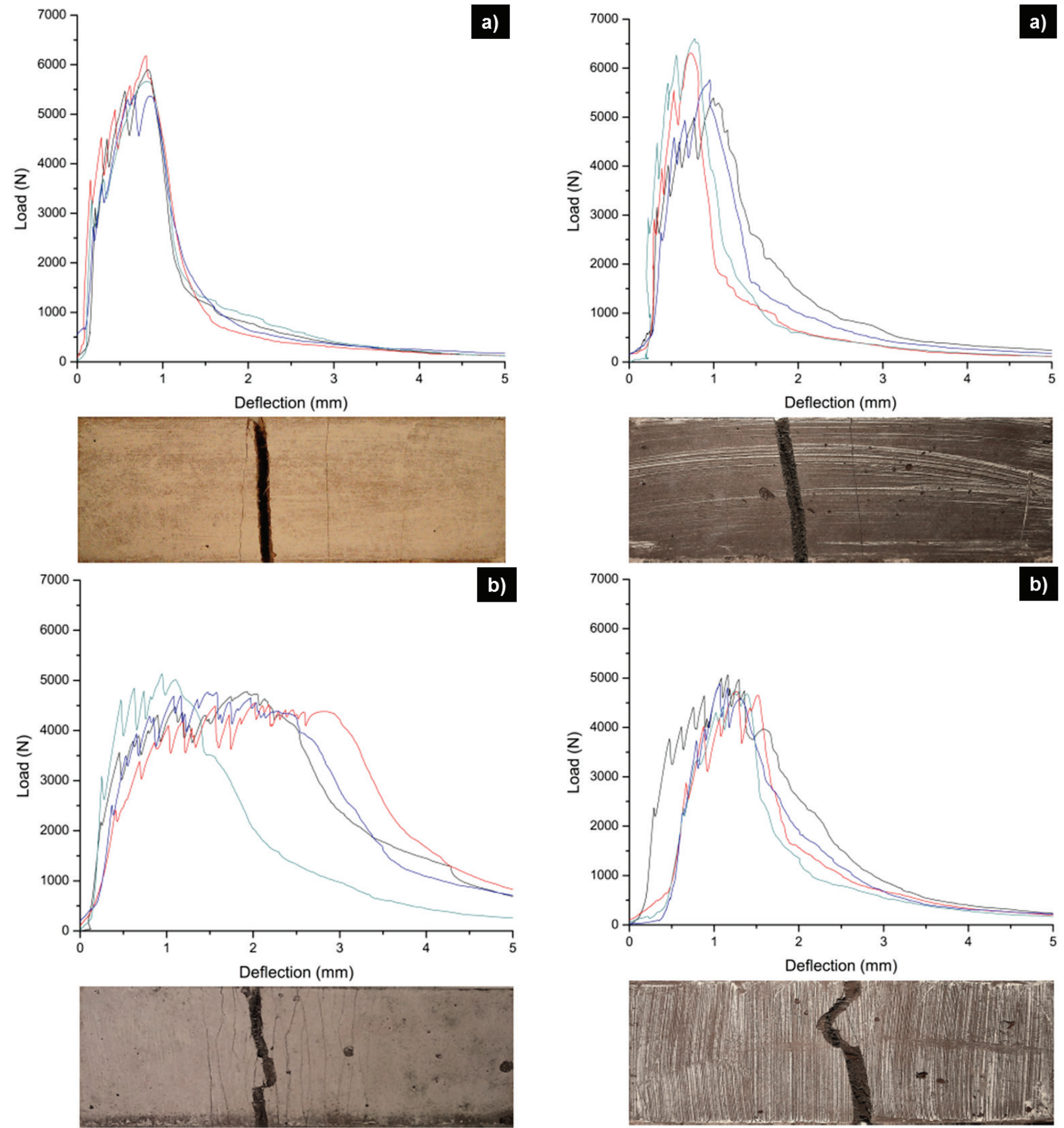

Figure 3. Load x mid-span deflection and cracked specimens for (a) NAT 3.0 100MK-00SF and (b) NAT 3.8 82MK-00SF mortars.

The employment of mine tailing as aggregate slightly increased the peak strength for a fixed $\mathrm{SiO}_{2} / \mathrm{Al}_{2} \mathrm{O}_{3}$ molar ratio; the toughness is not jeopardized when the mining tailing is used.

Figure 4. Load $x$ mid-span deflection and cracked specimens for (a) MT 3.0 100MK-00SF and (b) MT 3.8 82MK-00SF mortars.

Overall the results show that the mine tailing used does not affect the mechanical behaviour in flexion significantly; the composition of the matrix appears to play a major role in the adhesion with fibres and toughness. 


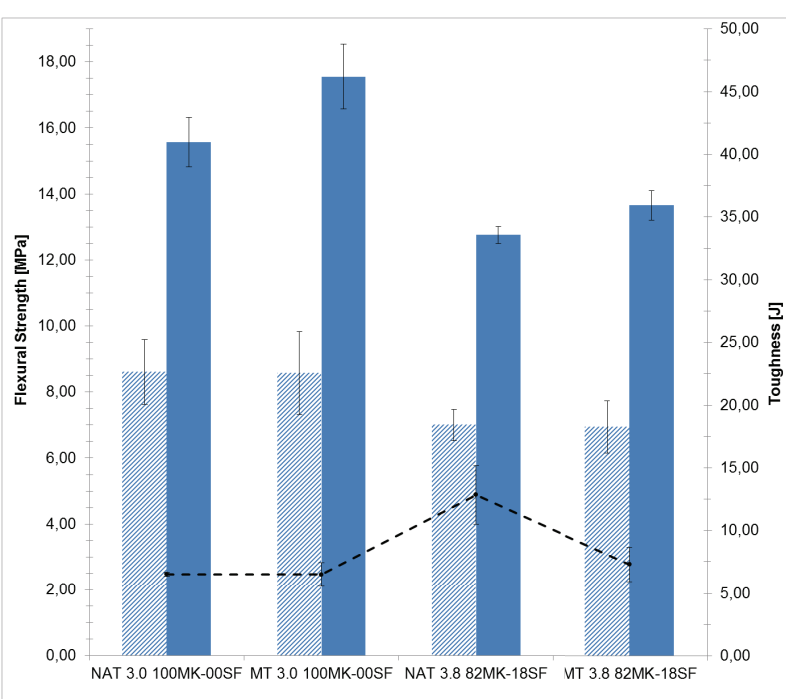

Figure 5. Average first peak (dashed bars), peak strength (solid bars) and toughness (line) of the four different AAM.

\section{Conclusions}

This study investigated the mechanical properties (compressive and flexural strength) of PVA-reinforced AAM containing either natural quartz aggregate or an iron-ore mine tailing. Irrespective of the type of aggregate used (natural or tailing), satisfactory results were obtained for matrices designed with $\mathrm{SiO}_{2} / \mathrm{Al}_{2} \mathrm{O}_{3}$ of 3.0 or 3.8. Overall, the employment of mine tailing slightly reduce the compressive strength, but the flexural strength and toughness is not affect; they are rather a function of the matrix composition.

The results presented in this paper indicate that ironore tailings may be effectively used in the production of ECC-AAM, with little or no processing (may be used as received). It is important, however, to investigate the durability-related properties of those AAM.

\section{Acknowledgements}

The authors would like to thank CNPq, CAPES, FAPEMIG and CEFET-MG for supporting this research.

\section{References}

1. P. Duxson, J. L. Provis, G. C. Lukey, J. S. J. Van Deventer. The role of inorganic polymer technology in the development of 'green concrete'. Cem. Concr. Res. 37 (2007) 1590-1597.

2. J. Temuujin, W. Rickard, M. Lee, A. Van Riessen, Preparation and thermal properties of fire resistant metakaolin-based geopolymer-type coatings, J. Non. Cryst. Solids. 357 (2011) 1399-1404. doi:10.1016/j.jnoncrysol.2010.09.063.

3. F. Škvára, T. Jílek, L. Kopecký, Geopolymer materials based on fly ash, Ceram. - Silikaty. 49 (2005) 195-204.

4. A. Palomo, M. W. Grutzeck, M. T. Blanco, Alkaliactivated fly ashes: A cement for the future, Cem.
Concr. Res. 29 (1999) 1323-1329. doi: 10.1016/S0008-8846(98)00243-9.

5. B. C. McLellan, R. P. Williams, J. Lay, A. Van Riessen, G. D. Corder, Costs and carbon emissions for geopolymers pastes in comparison to ordinary portland cement. J. Clean. Prod. 19 (9-10) (2011) 1080-1090.

6. L. K. Turner, F. G. Collins, Carbon dioxide equivalent (CO2-e) emissions: a comparison between geopolymer and OPC cement concrete. Const. Build. Mater. 43 (2013) 125-130.

7. A. M. Fernández-Jiménez, A. Palomo, C. LópezHombrados, Engineering properties of alkaliactivated concrete. ACI Mater. J. 103 (2) (2006) 106-112.

8. D. L. Y. Kong, J. G. Sanjayan, Damage behavior of geopolymer composites exposed to elevated temperatures. Cem. Concr. Compos. 30 (2008) 986991.

9. D. L. Y. Kong, J. G. Sanjayan, Effect of elevated temperatures on geopolymer paste, mortar and concrete. Cem. Concr. Res. 40 (2) (2010) 334-339.

10. A. Palomo, M. T. Blanco-Varela, M. L. Granizo, F. Puertas, T. Vazquez, M. W. Grutzeck, Chemical stability of cementitious materials based on metakaolin. Cem. Concr. Res. 29 (1999) 997-1004.

11. T. Bakharev, Resistance of geopolymer materials to acid attack. Cem. Concr. Res. 35 (2005) 658-670.

12. T. Bakharev, Durability of geopolymer materials in sodium and magnesium sulfate solution. Cem. Concr. Res. 35 (6) (2005) 1233-1246.

13. V. Li, T. Kanda, Innovations forum: engineered cementitious composites for structural applications. J. Mater. Civ. Eng. 10 (66) (1998) 66-69.

14. P. H. R. Borges, A Bhutta, L. T. Bavuzo, N. Banthia, Effect of $\mathrm{SiO}_{2} / \mathrm{Al}_{2} \mathrm{O}_{3}$ molar ratio on mechanical behavior and capillary sorption of $M K$ based alkali-activated composites reinforced with PVA fibres. Materials and Structures, 50 (2017). doi: 10.1617/s11527-017-1021-y.

15. C. Zanotti, Paulo H. R. Borges, A. Bhutta, N. Banthia, Bond strength between concrete substrate and metakaolin geopolymer repair mortar: Effect of curing regime and PVA fibre reinforcement. Cem. Concr. Comp., 80 (2017) 307-316. doi: 10.1016/j.cemconcomp.2016.12.014.

16. C. S. Bitencourt, B. H. Teider, J. B. Gallo, V. C. Pandolfelli, A geopolimerização como técnica para a aplicação do resíduo de bauxita. Cerâmica, $\mathbf{5 8}$ (2012) 20-28.

17. A. Sathonsaowaphak, P. Chindaprasirt, K. Pimraksa, Workability and strength of lignite bottom ash geopolymer mortar. J. Haz. Mat., 168 (2009) 44-50.

18. S. Songpiriyakij, T. Kubprasit, C. Jaturapitakkul, P. Chindaprasirt, Compressive strength and degree of reaction of biomass- and fly ash-based geopolymer. Const. Build. Mater. 24 (2010) 236-240. 
19. G. Kastiukas, X. Zhou, J. Castro-Gomes, Towards Preparation Conditions For The Synthesis Of Alkali-Activated Binders Using Tungsten Mining Waste, ASCE's J. Mater. Civ. Eng. (2017) 1-35. doi:10.1061/(ASCE)MT.1943-5533.0002029.

20. N. Sedira, J. Castro-Gomes, G. Kastiukas, X. Zhou, A. Vargas, A review on mineral wasten for alkaliactivated binders due to their chemical characteristics, Min. Sci. 24 (2017) 29-58. doi: $10.5277 / \mathrm{msc} 172402$.

21. J. L. Provis, V. Deventer, J. S. J., Geopolymers. Structures, Processing, Properties and Industrial Applications, (2009). doi:10.1533/9781845696382.

22. X. Jiao, Y. Zhang, T. Chen, Thermal stability of a silica-rich vanadium tailing based geopolymer, Constr. Build. Mater. 38 (2013) 43-47. doi: 10.1016/j.conbuildmat.2012.06.076.

23. IBRAM, Gestão e Manejo de Rejeitos da Mineração, (2016).

24. ABNT. NBR 7215: Cimento Portland Determinação da resistência à compressão. Rio de Janeiro, (1996).

25. ABNT. NBR 8522: Concreto - Determinação do módulo estático de elasticidade à compressão. Rio de Janeiro, (2008).

26. ASTM. ASTM Standard C 293-02: Standard test method for flexural strength of concrete (using simple beam with centerpoint loading) West Conshohocken, (2002). 